\title{
A comparative study on goals of competition law with the case of merger regulation and recommendations to Viet Nam
}

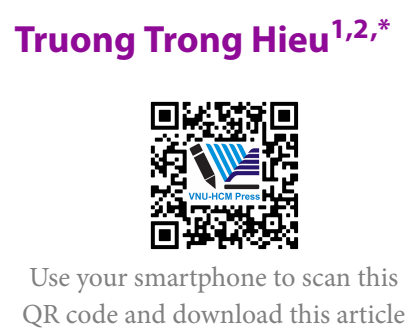

${ }^{1}$ University of Economics and Law, VNU-HCM, Vietnam

${ }^{2} \mathrm{PhD}$. Candidate, Yokohama National University, Japan.

\section{Correspondence}

Truong Trong Hieu, University of Economics and Law, VNU-HCM, Vietnam

PhD. Candidate, Yokohama National University, Japan

Email: hieutt@uel.edu.vn

History

- Received: $11 / 8 / 2020$

- Accepted: 10/11/2020

- Published: 13/2/2021

DOI : 10.32508/stdjelm.v5i1.684

\section{Check for updates}

\section{Copyright}

(c) VNU-HCM Press. This is an openaccess article distributed under the terms of the Creative Commons Attribution 4.0 International license.

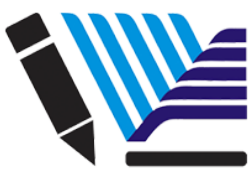

VNU-HCM Press

\begin{abstract}
The goals of competition law and policy play a notable navigator in law enforcement and lead to new rule inauguration regimes. However, Vietnam avoids signifying its goals in all two competition law versions, the Vietnamese Competition Law 2004 and the Vietnamese Competition Law 2018. The practical merger regulation has been thus confusing in the circumstances. Be continued with the lengthy controversial discussions in the academic world; the paper opens the comparative approach to other major jurisdictions. Rather than the Asian earlies system of Japanese anti-monopoly law or the European Union's primary youngest competition law, the United States antitrust law contributes to the original explanation of the law's objectives and directions. It experiences that Vietnam could maintain the diverse goals of competition law with its priority interests. Rejecting the aspect of free and fair competition, or the workable competition, the analysis traces the identification of effective competition mainly according to the European Union's perspective. Notably, the industrial policy takes a significant connection with the competition policy; however, it does not always ensure competition law enforcement. Be mainly based on Japanese historical achievement; the paper leads to an appropriate direction to resolve this complicated relationship between the two conflict but reciprocity policies. These implications will contribute to enhancing the legalization of competition law in Vietnam.
\end{abstract}

Key words: Competition law, competition policy, industrial policy, goal, merger regulation

\section{INTRODUCTION: VIETNAMESE IGNORANCE OF INSTALLATION OF COMPETITION LAW'S GOALS}

In developing an adequate legal institution for the market-oriented economy, Vietnam has recognized the competition law's critical role. Among many things that need regulatory descriptions, identifying goals for the law brings meaningful evolvement ${ }^{1,2}$. However, Vietnam has been nervous about such legislation because of a short period of experience for the reform building the new economic development model and the newly legal field of antitrust law. At least till the eve enactment of the VCL of 2004, Vietnam was like the white paper familiar with several strange concepts and notions of the competition law. More remarkably, there was an expertise idea that Vietnam did not have an unnecessary demand for independent competition law and could regulation market competitive behaviors by codifying other relevant laws instead ${ }^{3}$. As a result, Vietnam launched the VCL of 2004 without provisions concerning the goals of the law. This status remains unchanged after nearly fifteen years of implementing the competition law and policy in Vietnam.
Under the academic discussion, it has persisted a debate on this topic. Before the enactment of the VCL 2004, almost all discussions approached the law the freedom of competition. It exceptionally positioned the law from aspects to enhancing the freedom of business conducting ${ }^{4-6}$. They functioned the law to protect small business operators, consumers, and insurance for competition and public interests ${ }^{5,7}$.

For latter arguments, particularly in the adjusted bill of the VCL of 2018, the popular ideology has provided no much progressive change. It commonly targeted the competitive environment, which could further drive economic progress in manners of fairness and justice ${ }^{8}$. Continuously, the notions of free competition, consumer interests, and enterprises' competitiveness remained for the proposal sketching Vietnamese competition law's objectives ${ }^{2}$.

Indeed, other scholars also emphasized the goals for boosting the economic, industrial, and even trade advancements for competition law. The scholar considered the goal of fair competition protection as the method for state regulations to economic actions ${ }^{5}$. Also, there has been an expansion of competition law to different ministries' administrative activities because this proposed competition policy could supply the macroeconomic ground for competition law 
implementation ${ }^{9}$. They understood that it should be necessary for competition authorities to incorporate with other governmental agencies to halt anticompetitive appearances ${ }^{9}$.

The embarrassing approach could come from the original policy of competition in Vietnam. Aside from many statements for the competition law, which targets "the fair, regulatory and polite competitive environment," 10 and "the preservation of competition, the defeat of monopoly, unfair competition as well as restraints of trade" ( ${ }^{10}$ Sec. 4.1 and 4.2$)^{\mathrm{a}}$ Vietnam had faltered out the policy for competition and business collusions $\left({ }^{11} \mathrm{Sec} .4 .1,{ }^{12}\right)$. Remarkably, the scholar underlined that such an approach supplied the foundation for workable competition law in Vietnam $\left({ }^{11}\right.$ Sec. 4.1,12).

However, many arguments narrowed the conventional approach for the competition law in Vietnam, especially recent contributions. Commonly, the other economist soon identified the two side effects of competition: advantages and disadvantages for development also ${ }^{13}$. From the market failures under the regimes of "invisible hand" and its adverse outcomes, in the beginning, Tran Dinh Hao highlighted the essentials of the anti-monopoly act ${ }^{14}$. Among confusing discussions, Nguyen Nhu Phat and Bui Xuan Hai also characterized the competition law as the "antimonopoly law" with the manners of "restrictions, defeating and punishments" but the destruction of reasonable monopoly ${ }^{5,15}$. Nguyen indicated that the law merely combats unlawful monopolization and its abuse ${ }^{9}$.

More importantly, the Vietnamese Communist Party's policy also admitted such a new corresponding approach to the competition law's goals and functions. In the new Resolutions, Vietnam emphasized the target to "the effective control of business monopoly and effective and efficient implementation of fair competition policy" ( ${ }^{16} \mathrm{Sec}$. 4.1) and "the ensures of competition injustice and transparency for enterprises from all economic sectors." [i] Notably, in the $12^{\text {th }}$ National Committee of the Communist Party in Vietnam in 2016, Vietnam emphatically stated that it would put the state-owned enterprises into the market economy's mechanism and distinguish their business actives from political duties for the countries( ${ }^{16}$ Sec. 4.1$)$.

Unfortunately, the new VCL of 2018 remains silent on law goals even it has absorbed these perspectives for

\footnotetext{
aThe Communist Party of Vietnam, "The Resolution of the 9th National Congress of the Communist Party of Vietnam" (the National Political Publishing House, 2001) Sec. 4.1 of The Strategy for SocioEconomic Development 2001-2010.
}

different modifications. In actuality, Art. 6 regards the state's policies on the competition. Nonetheless, it would be the policies' goals, which are inclined to enhance competitiveness on the market and economy. Therefore, to certain extents, this concern stands for the industrial policy's approach. Ultimately, it could say that the issuance now flies without the mastered orientation for the statute's objective. Of course, it also influences the merger regulation; and, the embarrassed provisions relevant to the merger's appraisal factors and the procedure could exhibit this fact. Furthermore, it is strange that the law's goals were left behind even its bill had a grave concern.

It is anticipated that the future implementation of competition law without navigator remains challenging. Based on the previous mast debate, the writing will connect to the universal approach to competition law's goals for Vietnamese implications. Indeed, this approach becomes more and more popular under international integration, uniquely when scholars have determined that the law characterizes to be truthful, social and thus tends to be univer$\mathrm{sal}^{6}$. Vietnam mainly benefits it for harmony to the new generation of bilateral and plural agreements it has been signing. For Vietnamese competition law and its merger regulation, the comparative research method becomes important when current provisions do not supply the asymptotic formula in connecting with other outstanding jurisdictions ${ }^{17}$.

It begins with selecting compared legal systems, including Japan, the EU, and the US. The inclusion of three majority jurisdictions, which come from the three main parts of the world, could supply the universal confluence. Moreover, at the start, the dissertation aims for Japan and the EU to extract familiar experiences, and the United States to acquire a clear explanation for the origins. Notably, Vietnam seems to be familiar with the initial period of enactment and implementation of the JAA in Japan. In history, Japan was reluctant to adopt the strict antitrust law under the US Occupation after World War II. At the same time, however, it had a significant demand for rebuilding the economy collapsed for the War. For instance, Korea decided to drop the competition law bill for its industrial policy many times ${ }^{18}$. ${ }^{\mathrm{b}}$ It appears that Vietnam introduced the VCL of 2004 and even the current VCL of 2018 when it had not enough conditions for full and effective implementation, and there have been controversial ideas from the academic discussions $^{3,19-21}$. Thus, the experience from Japan will be significant for Vietnam.

\footnotetext{
${ }^{\mathrm{b}}$ The bill of competition law was dismissed in 1964, 1966, 1967, 1968 and 1972.
} 
Under this direction, the discussion would be followed by two main sections. First, it will come across the significant confluence of the US, EU, and Japan's goals within their competition laws. Of course, there exists an undeniable fact that the convergence lies by the divergence. Next, the following section leads to the manifest design of the Vietnamese competition law's goals. Notably, the suggestion introduces a distinction between competition policy goals and the standby industrial policy that frequently confuses the current debate. The discussion then closes with the Conclusion in which it states the importance of competition law with its apparent objectives. In particular, it presents worthy of remark outline for the convergent suggested goals of competition law in Vietnam.

\section{THE MAJOR CONFLUENCE OF THE US, EU, AND JAPANESE COMPETITION LAWS' GOALS}

\section{On the US incline in customer welfare protec- tion}

It should come with the US's goals in the antitrust law first. It was the matter when there had been controversial ideas on antitrust law goals in the US. The US Congress, during the time passing the Sherman Act, intended to deal with two things: Competition for protection and the monopoly for prevention ${ }^{22}$. The critical issue was that some initial discussions departed from the common law approach, particularly the contract law and the corporation law, surrounded by the "restraint of trade" in such legal perspectives ${ }^{23}$. Indeed, it was not easy to conclude that the common law of trade restraints concerns would not apply to modern antitrust regulation demands. It was challenged more and more when Sherman altered the bill's terminology, and the Sherman Act was passed with the words of "restraint of trade" at the beginning ${ }^{23}$. As a result, the considerations continuously went with the classical concept of "competition" under the classical economics theory, whose examination provided the "emphasis on liberty and freedom from coercion" ${ }^{23}$. Moreover, the base for the protection of competition in common law originally came from an ideology of social good. Even though under the basic inspired progression of the importance of competition, the processors remained nervous and usually thought about the "appropriate limits of competition policy" for "the same opportunity to all" 23 .
Nevertheless, some explanations maintained that Congress found a way to save "the equal opportunity and equal access for small business" with an explicit description that "concentration of resources in the hands of a few" was viewed as a social and political catastrophe as well ${ }^{22}$. Previously, George J. Stigler was also concerned about the opposition to big business for small businesses, which was parallel in addition to "the opposition came from areas with potential monopolizable industries." Exceptionally, he sent this argument even when he had identified "the actual inroads of large enterprises on small businesses were still in an early stage" 24 .

Others countered that the small business protection was not a US antitrust law's object in initial. Indeed, business efficiency was an obvious Congress' concern, which was why the parliament had never let the law interfere. Instead of other things, according to Robert H. Bork, the US antitrust law's most important objective was to protect customer welfare 25,26 . ${ }^{c}$ As a logic, it was to affirm that small producer could benefit from measures to such an achievement, which happened coincidently. In principle, the aim was that the small's interests must be rational and not be conflicting with consumer welfare. By contrast, Congress certainly "chose consumer welfare as decisive" 26-28.

Robert H. Bork previously explained that the court had no enough durable power to utilize different standards despite its broad discretion empowered by the legislature ${ }^{27}$. The idea existed even, for the practical aspect, the court came with the protection of small business, and override "its consumer-oriented goals," frequently ${ }^{26,28}$. The US Congress made a hint of the small producer in front of the paramount of consumer welfare. It was because it acknowledged that "the law should not interfere with business efficiency." Moreover, as Congress's determination, it was because "monopoly itself was lawful if it was gained and maintained only by superior efficiency." Contrarily, if small business protection was put into "an inch beyond the bounds of the consumer-welfare rationale" in the breaking monopolies of the antitrust norm could bring the backfire. It was because such inventions "would be to impose lower output and higher prices upon consumers" sometimes ${ }^{26,27}$. Therefore, Robert H. Lande concluded that it was not convenient

${ }^{c}$ There existed an argument that the US antitrust law officially turned toward this goal after the book The antitrust paradox: A policy at war with itself published in 1978.

${ }^{\mathrm{d}}$ Indeed, he intended to the business efficiencies but benefited consumers at the end. Notably, he usually based on the merger's merits for the arguments that the law did not need to interfere occasionally. Also, he early apposed the incipiency doctrine for the reason that it could halt these merger's efficiency. 
to bring the US antitrust law's historical aspect of protecting small producers as its end ${ }^{28}$.

Fortunately, small business interests and consumer welfare often came together and complementarily supporting each other to some extent ${ }^{27}$. According to many scholars, however, it would be apparent in looking up the Sherman Act's initial goals, one of the so old statutes with its more than one-century establishment, by such an Act's historical preceding. From that viewpoint, Robert H. Bork in 1966 based his research on the "legislative intent" and the first Sherman's attention on his previous bills ${ }^{27}$. Rudolph J. Peritz had a nearly similar approach while regarding "the primary strategy" and "their ultimate goal" of Sherman and others under the first bill of 1888 , which was to "enhance the consumer's well-being" 29 .

As a result, Robert H. Bork plainly stated that the Sherman Act's primary aim was to protect consumer welfare. Of course, the goal of protection to consumer welfare was on a rule applicable for monopolizing mergers, even in the US antitrust law in latter; however, the application "may appear less unequivocally to imply a consumer welfare rationale" ${ }^{30}$. Alongside the scenario for "full and free competition," Sherman, in the Speech clarifying his original bill, also implies the goal to "advance the cost to the consumer" 27,29 e Also, Sherman's statement may lead Robert H. Lande to more arguments in his writing in 1982. He found that the US Congress passed the Sherman Act for "further economic objects;" however, the basic one among them was the fair distribution of wealth. That was not fairness, wealth, or distribution in general and not "an efficiency nature" but, in other words, a promotion for wealthy distribution. According to Robert H. Lande, what one call for the Congress principal concern was to refrain "firms with market power" from unfairly divesting wealth. Indeed, the "competitive markets would bring" that nutrition to consumers, and other concerns in logic subordinated to "the basic purpose of preventing firms with market power from directly harming consumers" ${ }^{28}$.

For the same achievement as Robert H. Bork's, Robert H. Lande diversely discussed more other so-call objectives among Congress's intention and the Sherman Act's ancient world, such as productive efficiency, small business incentive, and social and political concentration. Thus, it resulted in a slight divergence, but

\footnotetext{
${ }^{\mathrm{e}} \mathrm{He}$ said, for example, that his bill sought "only to prevent and control combinations made with a view to prevent competition, or for the restraint of trade, or to increase the profits of the producer at the cost of the consumer" The important historical background is that, according to Robert. H. Bork, many senators in the US Congress at that time came to agree with this outline.
}

precision and variation of the direction of transformation on consumers' wealth, which in turn contributed to the protection of consumers' welfare ${ }^{28}$.

Extremely, Robert H. Lande regarded productivity, for example, as free competition, which in theory created "efficient competitors" at the beginning, for the affirmation that what gained from such a situation was primarily sent to consumers. According to Harry First, Robert Bork made his opposite approach when he, in latter, 1978, concerned the allocative efficiency for ignorance of other political values in "arguing for the Chicago School" 31 . For Harry First's counterargument, Bork provided his examination without determining the substantive language of the law. As a result, it drew down that the US antitrust law aims for the allocative efficiency and consumer interests in the thin concept ${ }^{31}$. However, it seemed that the monopolization would never "pass their efficiencies on to consumers" 27 in front of the fact that consumer prices increased higher than before ${ }^{28}$. It meant the consumers' interests would be extracted by such an "unfair price" under "unfair transfers" of wealth from consumers to monopolies ${ }^{28}$.

That may be why the leading economic theorists put the concept of allocative efficiency "on the verge" of their discovery. As Robert H. Lande cited, Senator Sherman explained that "it is sometimes said of these combinations that they reduce prices to the consumer by better production methods, but all experience shows that this saving of cost goes to the pockets of the producer." The suggestions for efficiency and big business promotion were, therefore, suddenly disappeared. The recommendation consequently boosted the US Congress' expectation of efficiency straight forward the "hypothesis of consumer welfare," what the courts should explain for their restriction on the adequate size in its turn also 27,28 .

In practice, the US does not aim at the Sherman Act's substantive language of the Clayton Act in the latter. From such discussions, one could identify the typical approach to the hypothesis of consumers' interests, particularly when this flag officially becomes the poster on the FTC's website ${ }^{32 \mathrm{f}}$ and the DOJ's confirmation even under the diversity of statements ${ }^{33} . \mathrm{g}$

${ }^{\mathrm{f}}$ It labels that "the antitrust laws have had the same basic objective: to protect the process of competition for the benefit of consumers, making sure there are strong incentives for businesses to operate efficiently, keep prices down, and keep quality up."

gIt defines that "the goal of the antitrust laws is to protect economic freedom and opportunity by promoting free and fair competition in the marketplace. Competition in a free market benefits American consumers through lower prices, better quality and greater choice. Competition provides businesses the opportunity to compete on price and quality, in an open market and on a level playing field, unhampered by anticompetitive restraints." 
Outstandingly, both agencies remain this approach to the merger regulation. They emphasize in the Merger Guidelines that:

- Regardless of how enhanced market power likely would be manifested, the Agencies normally evaluate mergers based on their impact on customers. The Agencies examine effects on either or both of the direct customers and the final consumers. The Agencies presume, absent convincing evidence to the contrary, that adverse effects on direct customers also cause adverse effects on final consumers $\left({ }^{25,34}\right.$ Sec. 1$) .{ }^{\mathrm{h}}$

\section{On the Japanese persistence of free compe- tition}

For the Japanese story, Harry First contributed much to studying anti-monopoly law goals, especially under the US's comparison. However, unfortunately, he found that "Japanese-language sources devote only slight attention to the origins of the Act." In actuality, the JAA's presence came from the outside force ${ }^{31}$. That was the US, as mentioned. The goal of the JAA, therefore, in the beginning, departed from the US approaches and suggestions for Japan.

The JAA concerns its goal into Art. 1. Nonetheless, it needs to come back with the original aims proposed by the Supreme Commander for Allied Powers (SCAP) among the US and Japan after World War II. At that time, it concerned "an equal opportunity for competition among participants." It also regarded the ignorance of the MITI's bill for the prewar law's resemblance to strengthened cartels ${ }^{31}$. The Japanese convention of the anti-monopoly law addressed a "connection between antitrust and deconcentration." Notably, it emphasized the destruction of the zaibatsu ${ }^{31}$.

Moreover, Japan also proposed its law to "increase market access" 31 . Harry First recognized the foundation that Japan subjected to "the importance of competition in open markets," and made much concentration on small business who seemed to be harmfully targeted by the big companies' exclusive actions. As the active treatment, however, Japan did not abandon "larger firms," and the US at the end must agree that the preservation of "scale economies" needed to remain as "a continuing theme" on the Japanese norm of antitrust law ${ }^{31}$.

Even in pursuing the promotion of "free competition" for the economy ${ }^{35}$, Japan also made its proposal for the "national economic welfare," even though the US

\footnotetext{
${ }^{\mathrm{h}}$ In practice, this approach remains to get counterarguments.
}

did not regard it in its draft. In history, consumer protection employed from the original model of the US mentioned in Art. ${ }^{36}$ did not make much sense to Japan, mainly because of two reasons: the Japanese economy's demand, and the traditional Japanese approach of "a bureaucratic regulatory culture" 37 . In order words, Japan sounded to sacrifice consumer welfare, at least in the short-term, even in theory, the increase in consumer benefits could bring the rise of the national interest.

Another context in the Japanese goals of antimonopoly law enforcement was the "public interest." Under Wakui Masako's research, it was one of three underlying regimes of Japanese anti-monopoly law's

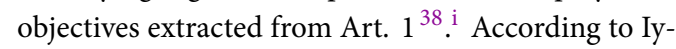
ori Hiroshi, like what Masako analyzed, the JAA conducts this aim mainly to restrict "unreasonable restraint of trade" under chapter II, which takes place for the private monopolization ${ }^{39}$. Japanese merger regulation later made it divergent for the definition of "unreasonable restraint of trade" from this aspect. In reality, the interpretation of this phenomenon under the Japanese perspective has been different from the US's application of a similar test under the Sherman Act $^{39}$.

Overall, what is addressed in Art.1 makes sense regarding the goals of the Japanese anti-monopoly regime. Among the diversity of critical objectives, the promotion of "fair and free competition" seems to be the underlying principle due to its initial statement in the Article and its clear definition in the Art. $2^{4}$. And, the phrase "and thereby... secure the interests of general consumers" ( ${ }^{40}$ Art. 1 ) could mean that the protection of consumer's interests remains significant and becomes a priority even though it has not appeared frequently ${ }^{41,42}$.

Regarding how this objective locates, one could recognize that it has resulted from the foremost goals and the specific branch of law. In the merger regulation, the JFTC's Merger Guidelines sounds to be familiar with the US approach. Explicitly, it defined the market power, or the outcomes of "lessening competition," raised by the merger as consequences of decreasing output, diminishing innovation, or otherwise harmful conditions to customers rather than what is expressed in general in the Art. $2^{4}\left({ }^{34} \mathrm{Sec}\right.$. $1,{ }^{43}$ Part III. ${ }^{1}$.B.).

Japan has a sophisticated approach in determining the goals for the anti-monopoly law. The interpretation needs more practical aspects, which could make

\footnotetext{
${ }^{\mathrm{i}}$ Two other regimes consist of the promotion of fair and free competition and the protection of consumers' interests.

j"the JAA" Art. $1 \& 2$.
} 
Japan's direction altered in practice because of, for example, the various targets in economic development, especially the incentives for industrial policy. Therefore, it contributes to supply the diversity for Japan's approach even though it seems to approach the protection of consumer welfare like the US.

\section{On the EU inauguration of effective compe- tition}

It would not be too strict in tackling the EU competition law's goals. Initially, in almost all situations, the discussions first and foremost mentioned the EU's attempts in making rules for the protection of competition, particularly the process of competition, then moved to the other afterward. Overall, the EU's fundamental competition rules were for the "vibrant and competitive economy" ${ }^{44,45}$.

On the one hand, the experts applied the competition policy to the "allocative efficiency" ${ }^{46}$. When there appeared problems, notably raised on the neo-classical economic theory of perfect competition, on the other hand, the emphasis gave a movement, even from the "fairness and economic freedom," for the workable competition, or contestable markets ${ }^{1,47-49}$. Ulti- $^{-}$ mately, the concept of "effective competition," the best imperfect competition," stops the arguments as a significant achievement for the EU's competition law ${ }^{48-50}$.

The most crucial legal inclusions for this aim are the legal documents for competition law in the EU. From the ECT to the TFEU, the EU has remained to regard "competition," notably the "fair competition" on the preamble ${ }^{51}$. However, in practice, the EU court expanded the objective to the "effective competition" 52,53 . As a result, for this goal, both the EU Merger Regulation 1989 and the EU Merger Regulation 2004 attempt to combat incompatible mergers for "the need to maintain and develop effective competition in the common market" $54,55 \mathrm{~m}$. This objective accordingly has spread broadly till now.

Notwithstanding, the ongoing discussion emphasizes the EU's competition law to address consumer welfare ${ }^{19,20,48}$. The EU merger regulation could not lose this pathway on direction against the adverse effects of the marker power or monopolization ${ }^{56}$. Therefore, the arguments suggest that the merger's substantive test mostly concerns consumers' "expense" on anticipating its anti-competitive effects ${ }^{57}$. In other words,

\footnotetext{
${ }^{\mathrm{k}}$ The goals were frequently mentioned before the EU economic modernization.

${ }^{1}$ Art. 81,52 Art. 85,53 Art. 102

${ }^{\mathrm{m}}$ For example, recital 14 for the former citation and the recital 23 for the latter one.
}

competition agencies must evaluate the merger based on "its impact on consumer surplus" ${ }^{8}$, and the application of remedies for anti-competitive mergers provide a matching contribution ${ }^{59}$.

The others also prove the multi-approaches in outlining the EU competition law's goals ${ }^{50,60,61}$. ${ }^{\mathrm{n}} \mathrm{Re}$ cently, Gerbrandy Anna has ever based the discussion on the EU "economic constitution" to aim the goals of competition law for its internal market modernization. The study attempted to prove that it would not be necessary only to bring the competition policy for consumer protection ${ }^{47}$. In his Speech in 2001, the previous Commissioner Mario Monti stated that "the goal of competition policy, in all its aspects, is to protect consumer welfare by maintaining a high degree of competition in the common market." He meant that, on protecting consumers' interests, the merger control would not be "against mergers that create more efficient firms" 62 . Unsurprisingly familiar, Georges Vallindas also concerned about the ultimate consequence of reducing prices for consumers even mentioned the industrial policy with its promotion of "optional allocation resources" ${ }^{46}$.

This aspect has attracted much attention and supports. On top of the writing, Esteva Mosso Carles also made sure that the merger control rules need to preserve the "competitive market structures" along with ensuring that "consumers fully enjoy the benefits of competition $^{63}$. Other scholars also considered the consumer welfare "in the technical at all," and require the competitive process for the market. They interpreted that the allocative and productive efficiency of such a process of effective competition also results in consumer benefits ${ }^{48}$.

As a result, the EU Merger Guidelines 2004 and 2008, for example, officially clarify that the "effective competition" that the EU merger regulation aims to protect and preserve would "bring benefits to consumers" ultimately ( ${ }^{55}$ at para. ${ }^{8,60,64}$ at para. ${ }^{10,65}$ ). Under Monti Giorgio's observation, the EU moves towards economic efficiency and consumer welfare other than competition and the internal market's integration ${ }^{1} .^{\circ}$ In detail, the effective competition on the market could contribute to the "low price, high-quality products, a wide selection of goods and services, and innovation" ( ${ }^{64}$ at para. ${ }^{10,66}$ at para. ${ }^{8}$ ). The protection of competition in merger control, in turn, benefits consumers regularly. As Johannes Laitenberger's new

\footnotetext{
${ }^{\mathrm{n}}$ Also, it is impossible to identify the single goals of competition law in either the US or the EU.

"Among there "core" values of competition, market integration, and economic efficiency, the EU in the past also aimed the last value at consumer welfare.
} 
Speech, the EU competition law with its a-few-yearold infant merger control ensures consumers' profits from products and services even though it has supplied different thorough 25 years ${ }^{67}$.

It is practical to focus that the law's individual goal supplies the similarity and, particularly, differences among legal systems. To a certain extent, along with the specific diverse approaches, the common objectives could converge these countries in theoretical and practical aspects. Indeed, one could recognize the conventional approach in competition law goals in the EU from the US and Japan perspectives. In practice, the US's "ideas, theories, and insights" affect the cEU's debate and even "rage over the application of EU rules" ${ }^{49}$. For example, Georges Valindas has cited Richard Posner for the recent discussion on "the only legitimate aim of competition law" ${ }^{46,68}$.p

\section{THE MANIFEST SKETCH OF COMPETITION POLICY'S GOALS IN VIETNAM}

\section{The necessary emphasis on the diverse objec- tives}

To aim the law to restrictions on anti-competitive behaviors, monopolizing processes, and any activities against the competitive environment, the explanation on the bill of competition law's adjustment in 2018 expressed that the new law on competition directs to the protection of fair and justice competition and thereby supply the driving force to economic development ${ }^{69}$. Soon before, the bill also stated that competition law needs to bring the goals to protect the enterprises' and consumers' legal interests $^{70}$. It sounds that the law functions brighter than the previous version; however, as seniors, the bill was confusing in front of the law's multi goals. Of course, it could be simple to follow the regimes of unified interest rather than plural ones, such as the workable competition concentration as the Chicago school's approach ${ }^{71}$. The selection comes with the reason that it is not always easy to combine diverse objectives ${ }^{71}$. The convergence and divergences of the US, Japan, and EU's competition regimes could tell meaningful stories.

The above discussion sounds that these three legal systems converge to protect consumer welfare at the end. More excitingly, Japan and the EU are closer to their multi-approaches in the competition law's objectives, even though the EU merely appears bright with the statement that "effective competition brings benefits

p For an historical perspective of the Chicago and Harvard Schools to consumers," for example, in its merger regulation ( ${ }^{64}$ at para. ${ }^{10,66}$ at para. ${ }^{8}$ ). The EU historical enforcement also evidenced the consumer welfare in its contribution ${ }^{44}$. Of course, it should note the small but significant difference between the EU and Japan, in which the EU regards the "effective competition" otherwise the "fair and free competition" of Japan.

In actuality, the analysis of Japan's approach above reveals that Japan has been unsurprisingly reflecting the perspective of more complex plural interests. In Art. 1 of the JAA, Japan pronouns that the purpose of the law is:

- to promote fair and free competition, stimulate the creative initiative of enterprise, encourage business activity, heighten the level of employment and actual national income, and thereby promote the democratic and wholesome development of the national economy as well as secure the interests of general consumers $\left({ }^{40}\right.$ Art. $1)$.

In practice, several countries have turned the competition law to solve various problems like Japan and the EU; however, they popularly highly select only one concern as the priority ${ }^{3,41,71}$. Brightly, the EU does not often aim the competition at its end, but mainly for consumer interests. For Japan, the expression appears to be that it mainly targets the preservation of competition, and "thereby," the consumers' interests would be the primary outcomes of such a promotion, especially in merger regulation.

It seems that the US does not count many goals for its antitrust law. In history, typically, it intended to halt trust and economic concentration. Like one of Japan's goal, it thus concerned "public interest" and was not reluctant to recognize "advantages of cheapness or better service which honest, intelligent cooperation may bring" at the same time ${ }^{72}$. One could find the approach to public interests in cases of Standard Oil Company of New Jersey et al. v. United States (1911), United States v. American Tobacco Company and American Tobacco Company v. United States (1911), or Brown Shoe Co. v. United States (1962).

However, the school of Chicago's arguments has changed the US approach in the 1970s. Be running far away from "the progressive or populist political preferences," the merger regulation as well as the antitrust law in general, the discussions aimed the sole goal to the "consumer welfare" 73 . Consequently, almost all mergers have been recognized with their efficiencies, which, as economic logic, benefit consumers at the end ${ }^{74,75}$. Thus, the merger review has begun to challenge mergers whose effects have been not cost-saving 
mostly or, in contrast, increasing prices or reducing market outputs ${ }^{75}$.

Of course, there have been controversial ideas that the law needs to consider other criteria such as, for example, to restrict the big business's impacts and send a promotion to the small alongside such protection of consumers, significantly as affected by the populist from the 19th century ${ }^{14,75,76}$.q Alternatively, some counterarguments pointed out the massive consumption of consumer welfare standard, which "has allowed too many mergers to create too much concentration in too many markets" 77 . Ultimately, market power has become the most critical concern in the merger regulation ${ }^{78}$. When the merger generates benefits, such as the economic scales' efficiency, it could favor consumers. Adversely, the merger law could detect and prohibit market powers, leading to monopolization and ten to injure consumers in the future. The other jurisdictions accordingly have converged with the $\mathrm{EU}$ at this point.

Of course, the suspension of the VCL means that Vietnam finds challenges in mastering the objectives for its competition law. Under the market power approach above, the perspectives of Japan and the EU could contribute significant experience. It implies that the primary goal of the merger law needs to be the protection of competition because it, in turn, would bring other effects to the market as well as consumers and other market players. Moreover, "thereby," from the problems of market power raised by the business plan, the merger regulation could anticipate the lessening competition from various aspects, including the decreasing output, releasing innovation, or other types of dangers on consumers ( ${ }^{34} \mathrm{Sec} .{ }^{1,43}$ Part III. ${ }^{1}$.B.).

Some scholars in Vietnam also made acquainted with this prospect. They identified that the law, which is to protect competition, is to protect the market and other economic factors, such as consumers. However, they included the enterprise and other business operators into the "other economic factor" 79 .

Currently, it evidences that Vietnam has approached the plural interests regarding the goals for the competition law in general. The scholars proved that competition law in Vietnam needs to ensure various kinds of interests ${ }^{3,9}$. To be familiar with this approach, Vietnam needs to have perceived its necessary emphasis $^{3,71}$. Indeed, the construction of regulatory priorities should depend upon the economic foundation ${ }^{80}$. Mostly, to absorb this approach, the writing proposes that Vietnam should pay attention to the "effective

\footnotetext{
${ }^{\mathrm{q}}$ As cited from Hans B. Thorelli, The Federal Antitrust Policy, 180$85,1955$.
}

competition" experienced from the EU's aspect. Naturally, the "free and fair competition" has become ancient and may lead to some obstacle for the economy nowadays ${ }^{48,49}$. As suggested by some Vietnamese scholars $^{71}$, the approach to the workable competition also brings meaningless evidence ${ }^{48,49}$. Overall, to achieve the market with effective competition and priority of consumer welfare could bring the law opportunities to restrictions on anti-competitive treatments as what preference of law, the scholars pointed out $^{3}$.

\section{To an apparent position of the industrial policy}

The discussions in OECD's round table in 2009 showed that competition policy in practice could play as a useful tool for backing to industrial policy's performance to the stable economy in scale effect. It can primarily prevent the domestic market from foreign monopolistic companies' predatory pricing activities, make a driving force to new industries, and reforms of technologies and management for companies' accomplishment ${ }^{80}$. Interestingly, competition policy can exist whenever an industrial policy's positive impacts do not balance enough malicious attacks by anticompetitive reactions ${ }^{81}$. Therefore, the implementation of industrial policy should position in a parallel stage with competition policy, and vice versa, for the provincial economy's productivity.

What happened in Japan in history can be an interesting illustration of "obvious success and understandably legitimized government intervention in the economy" ${ }^{82}$. Partially, it was of the vigorous enforcement of industrial policy for the relationship between enterprises and investment, which, as Japanese recognition, was the driving force for its historical hot economic development ${ }^{83}$. In other words, the relaxation of competition law enforcement played an essential role in contributing to the Japanese priorities in economic reconstruction ${ }^{84}$. At the time, the JFTC and MITI had no visible "animosity" after the JAA adjustments in 1953. At that time, the legislation became more relaxation reacting to the vivid elasticity of economic conditions and its relevant industrial policy ${ }^{84,85}$. It thereby released the JFTC's burden in front of the new competition policy.

In merger control, merger plans face the prohibition only when they were "may substantially restrain competition," or when "unfair trade practices have been employed" in the course of transactions ${ }^{85-87} . \mathrm{r}$ The

\footnotetext{
${ }^{\mathrm{r}}$ The most important additional rule in the amendment 1953 was the unfair business practice. Moreover, it should be noted that the base of "substantially restrain competition" was also enacted for cartel regulation. It means the cartel per se illegal was deleted.
} 
critical base of "substantially restrains competition" was continuously allayed any merger which even substantially restrains competition in any particular field of trade was still approved if "it is particularly necessary for the attainment of rationalization." It resulted that "the number of violation cases taken by the JFTC was decreased" in response to the new regulation with the "co-called preventive or supplementary provisions concerning restrictive business practices were deleted from the JAA" 88 .

It can be said that the motivation for these changes came from the factual elements in the Japanese economy and society. The termination of the Japanese Korean War with the Peace Treaty in 1951 had significantly affected, resulting in the alteration in the United States' policy to Japan, which played a vital role in the Japanese economy at the time $36,81,83,87,88$. Accordingly, such an attitude was towards "allowing the smoother and easier introduction of foreign capital and procurement of capital which were very much needed for Japan to attain economic reconstruction more rapidly" 88 .

Of course, these circumstances got down, the role of industrial policy did not have enough reasons to justify, the revitalization time of competition law and policy started, and JAA's enforcement has become more and more durable. Instead of the subordinated tenets among the competition and industrial policy before the 1990s, like the typical model, the Japanese competition law nowadays, on the whole, includes "more clout" and "more powerful, independent, visible, and active" ${ }^{89}$. Indeed, it has more demand for actively enhancing the JAA even though it has already directed "the value of competition and markets" ${ }^{89}$. Alongside tackling competition law goals and pursuing them, if introduced, Vietnam needs a clear insight into the industrial policy and different policies and legal frameworks for trade and economic development. It does not mean that Vietnam should eliminate such policies. However, it is reasonable to suggest a distinction in which Vietnam could find the appropriate pathway in incorporation with the competition law and policy implementation.

There are several pieces of evidence that Vietnam has much underlined the industrial policy. The remarkable proof could be the emphasis on the development of state-owned enterprises ${ }^{90}$. The Resolution of the National Congress of the Communist Party of Vietnam in 2001 strongly presented its statement to bring such actors as national champions to enhance their

\footnotetext{
${ }^{\mathrm{s}}$ Moreover, such a US' policy was considered as a way to make Japan as 2bulwark against communist infiltration" in East side of the world.
}

domestic and international competitiveness. ${ }^{t}$ More importantly, the VCL 2018 also reflects this aspect at Art. 6. Undoubtedly, these orients come at a price $^{90}$, especially for the approach that, for the domestic enterprise and economy's strength, the competition law's existence under the several improvements of market-oriented institutional plays a vital role ${ }^{91}$.

By contrast, alongside the Vietnamese economy's immature entrepreneurship, there was even the idea to deny the competition law's soon existence, especially the extreme restriction as to the western model ${ }^{3}$. Others argued that Vietnam, which seems to have a strong demand for government support from the industrial policy on the initial economic transformation progress, lacks conditions to enforce the competition policy ${ }^{12}$. However, the current debate rejected the suggestions that other relevant laws could drive the competition policy, and even different norms such as, for example, bankrupted dissolutions or market natural extortion, could turn corporations into effective ways ${ }^{3}$. The opponents argued that other laws find challenges to function as the competition law's hands ${ }^{80}$. As a result, the Vietnamese competition law was born.

It is not strange when Vietnam still introduces its industrial policy. Nonetheless, Vietnam has been currently confusing in the involvement of competition policy and industrial policy. The previous mention of the embarrassing targets on competition in tandem with collusion could prove that Vietnam had no solutions for the peaceful relationship between these two policies. At least, Vietnam presents no drastically definitive statement for competition ${ }^{90}$. For the same situation where there has been the existing competition law, Vietnam could learn Japan to select the priority policy. Yes, it at first need a distinction between the competition policy and industrial policy.

However, it should be aware that Japan permitted a justified policy on the industry in history when it did not provide much consumption of merger remedies. Undoubtedly, merger remedies could not function to implement the industrial policy, but it could clear the desirable mergers that could meet the industrial policy achievement. In other words, the direction of mergers could go on even it has not needed more relaxation on competition law. More importantly, the proposed mergers also provide not anti-competitive effects with appropriate merger remedies.

In practice, Vietnam challenges to obligate the policy to enhance state-owned companies' effectiveness; and tackle the practical aspect that the existing monopoly

\footnotetext{
${ }^{\mathrm{t}}$ Sec. 4.1 of The Strategy for Socio-Economic Development 2001-
} 
mostly comes from such a business sector ${ }^{91}$. It especially made sense when the state-owned company was under the Ministry of Trade and Industry, which has also been authorized to implement the competition law and policy in Vietnam ${ }^{91}$. In several circumstances, moreover, Vietnam positioned other Ministries as dispute settlers in merger cases. For example, the Ministry of Information and Communications has mainly stood in the cases of VNPT and Viettel and EVN Telecom and Viettel ${ }^{91}$.

In practice, the context of industrial policy in Vietnam has been changing in front of the policy toward competition. Vietnam recently stated that it aims to put the public sector and private one into an equal competing ground under the market-based mechanism( ${ }^{16} \mathrm{Sec}$. 4.1). However, there is an obstacle in which there has been misunderstanding about the state economic sector's position. For instance, the present ideas may not identify that the state-owned economy's concentration does not mean that Vietnam aims to create and maintain a monopoly ${ }^{13,91}$. Notably, the accessible insight has been a not clear distinction of the monopoly's harmful effects and the ineffective factual management in state-owned monopolist $^{71}$. These have affected to solve problems on the relationship between the industrial and competition policies in Vietnam, particularly for the business sector of state-owned enterprises. As a result, there has been a tendency toward industrial policy's goal even if there is an existing statement that the implementation of competition law needs to be more strengthened. One more time, Vietnam has a remaining pathway in the VCL 2018. In detail, it also provides that other ministries shall corporate with the competition authority for "the state management of the competition" ( ${ }^{92}$ Art. 7.3. ). It should be to remind that, after the period of the industrial policy's dominance, Japan makes JFTC strengthen and independent. Other governmental agencies also construct their Divisions of competition; however, these latter ones play roles in enhancing competitiveness as partially the industrial policy targets. Notably, the MITI also has its competition division, but it does not remain the competition policy implementation as in history. In brief, Vietnam needs to concern the problems when it calls for other administrative authorities in making competition law enforcement.

In the final, it should restate the suggestion that Vietnam needs an apparent distinction between competition law and industrial policy. It is even that Vietnam could maintain and send its industrial one preference but in the other active pathway. Under the perception that competition law does not prohibit the monopoly, it just supplies the restriction on unlawful monopolization and monopolist's treatments ${ }^{93}$. As a result, the most vital tool to avoid the conflict between these two policies, Vietnam needs to aim its successful merger enforcement to merge remedy applications as others $^{74}$.

\section{CONCLUSION}

The goals of competition law and policy play a notable navigator in law enforcement and lead to new rule inauguration regimes. However, Vietnam avoids signifying its goals in all two competition law versions, the VCL 2004 and the recent VCL 2018. There appears an increasing debate in the academic world in which competition law goals have been outlined in several ways.

Indeed, Vietnam has a demand to look at more developed countries for future policies to harmonize merger control law. According to some experts, Japan's experience can "provide useful lessons" for developing countries or transitional economies ${ }^{94}{ }^{\mathrm{u}}$ Moreover, Japan is the leading country participating in merger deals in Vietnam, which is forecasted to continue in the coming years ${ }^{95-97}$. Aside from the US, Japan, and the EU merger regulations, there are suitable choices in a comparative study.

Overall, it implies that Vietnam, in its current progress, could remain the diverse objectives for competition law enforcement. Under the approach to plural interests, Vietnam must identify ones, or only one, for priority. From other legal systems' perspectives, it sounds that Vietnam should mainly direct the "effective competition" particularly experienced from the EU's aspect. Traditionally, the "free and fair competition" may be fluently perceived, but it seems too abstract and outdated. The formula of workable competition could supply significant aspects that impact the enhancement of firms' competitiveness. Finally, consumer welfare could have remained for further achievements. At present, effective competition could partially target this goal.

Notably, Vietnam needs to maintain the distinction between competition policy and industrial policy. These two policies usually run along but for two different goals, which could be a conflict or reciprocity sometimes. The enforcement of competition law and policy meets the industrial policy's demand in the circumstances does not pronounce that the two regulations always supply familiar outcomes. Of course,

\footnotetext{
${ }^{u}$ The researcher pointed out that "the text of a legal transplant is only one important consideration. Additionally, the context of competition law and the subtext of changes to the existing norms of economic regulation may be just as important to 'importing' antitrust law into developing nations or transitional economies."
} 
Vietnam could not destroy this for that one. However, to experience Japanese historical treatments, Vietnam could find the appropriate direction to peacefully execute the industrial policy under supporting conditions of the competition law and policy.

As navigators, the stipulated goals would drive law enforcement precisely and powerfully. Not only merger regulation but also other branches of competition law need to be motivated by these pilots. Thus, further studies of competition law goals must expand into regulations on the cartel, market dominance, et cetera. Future research on merger control necessarily concerns how the legal goals drive the merger review, particularly in assessing mergers' outcomes. In all, practical enforcement under the pilot of competition law objectives has a significant demand for deep consideration.

\section{ABBREVIATIONS}

DOJ The (US) Department of Justice

ECT The European Economic Community (EEC)

Treaty (the Treaty of Rome in 1957)

EU. The European Union

FTC The (US) Federal Trade Commission

JAA The Japanese Antimonopoly Act

MITI The (Japan) Ministry of International Trade and Industry

OECD The Organization for Economic Co-operation and Development

TFEU The (EU) Treaty on the Functioning of the Union

US The United States

VCL Vietnamese competition law

\section{CONFLICTS OF INTEREST}

The author declares that she has no conflicts of interest.

\section{AUTHORS' CONTRIBUTIONS}

Truong Trong Hieu has done all works of the article as a sole author.

\section{REFERENCES}

1. Monti G. EC competition law. Cambridge: Cambridge University Press. 2007;p. 527.

2. Huan PH. Các tiêu chí đánh giá tác động hạn chế cạnh tranh trong tập trung kinh tế [Criteria for evaluating economic concentration's competition restriction]. The Legislative Studies, Vietnam. 2017;15(343):37-43.

3. Nghia PD. Pháp luật cạnh tranh Việt Nam: Nhu cầu, khả năng và một vài kiến nghị [Competition Law in Vietnam: Demands, potential application and some suggestions]. State and Law Review, Vietnam. 2000;11(151):29-35.

4. Minh ND. Một số vấn đề về pháp luâat canh tranh trong bước chuyển sang nền kinh tế thị trường ở nước ta [Several issues of competition law on a progress toward the marketoriented economy in Vietnam]. State and Law Review, Vietnam. 2001;1:21-32.
5. Hai BX. Mục tiêu và phạm vi điều chỉnh của Luật cạnh tranh [The goal and scope of commpetition law]. State and Law Review, Vietnam. 2004;2(190):43-51.

6. Phat NN. Luật so sánh và thực tiễn xây dựng Luật cạnh tranh của Việt Nam [Comparative law and the fact to establishment of competition law in Vietnam]. Hanoi Law Review, Vietnam. 2007;4:43-48.

7. Thanh DV. Cạnh tranh bình đẳng vì sự phát triển [Equitable competition for development]. The Legislative Studies, Vietnam. 2004;6:35-38.

8. Phat NN. Luật Cạnh tranh năm 2018 và việc khắc phục những bất cập của Luật Cạnh tranh năm 2004 liên quan đến kiểm soát hạn chế cạnh tranh [Competition Law 2018 and overcoming inadequacies of the Competition Law 2004 on competition restriction control]. State and Law Review, Vietnam. 2019;6:32-52.

9. Phat NN. Nghiên cứu pháp luật cạnh tranh trong bối cảnh sửa đổi Luật cạnh tranh năm 2004 [Research of competition law in the context of the revision of the Competition law 2004]. State and Law Review, Vietnam. 2017;7:48-59.

10. The Communist Party of Vietnam. The Resolution of the 8th National Congress of the Communist Party of Vietnam. The National Political Publishing House. 1996;.

11. The Communist Party of Vietnam. The Resolution of the 9th National Congress of the Communist Party of Vietnam. The National Political Publishing House. 2001;

12. Hong TTQ. Luật cạnh tranh trên thế giới và ở Việt Nam: Sự hình thành và những nội dung cơ bản [Competition law over the world and in Vietnam: Formation and Basic contents]. Law Science Information (Institution of Law Science, Ministry of Justice). 2017;(3):4-10.

13. Doanh LD. Những vấn đề cơ bản về chính sách cạnh tranh và pháp luật cạnh tranh [Basic issues of competition law and policy]. State and Law Review, Vietnam. 2000;11(151):11-22.

14. HaoTD. Pháp luật cạnh tranh trong điều kiện chuyển sang nền kinh tế hàng hóa nhiều thành phần theo cơ chế thị trường ở Việt Nam hiện nay [Competition law on conditions toward the market-oriented diverse sectoral economy in Vietnam today]. State and Law Review, Vietnam. 2000;11(151):23-28.

15. Phat NN. Độc quyền và xử lý độc quyền [Monopoly and monopoly control]. State and Law Review, Vietnam. 2004;8:45-48.

16. The Communist Party of Vietnam. The Resolution of the 12th National Congress of the Communist Party of Vietnam. The National Political Publishing House. 2016;

17. Thanh PV. Đánh giá những điểm hạn chế, bất cập và định hướng cơ bản trong quá trình sửa đổi Luật cạnh tranh [The limitations and inadequacies' assessments and basic orientations for revising the Competition Law]. In: The Conference Proceeding. Hanoi: Hanoi Law University - FES institution. 2017;p. 223.

18. Jung $Y$, Chang S. Korea's Competition Law and Policies in Perspective Symposium on Competition Law and Policy in Developing Countries. Northwestern Journal of International Law \& Business. 2006;26(3):687.

19. Pham A. Development of Competition Law in Vietnam in the Face of Economic Reforms and Global Integration, The Symposium on Competition Law and Policy in Developing Countries. Northwestern Journal of International Law \& Business. 2006;26(3):547.

20. Quang TH. Cơ quan quản lý cạnh tranh tại Việt Nam: Thực tiễn và giải pháp đổi mới nhìn từ mô hình thế giới [Competition authorities in Vietnam: Practical Reform and Solutions from the world's models]. Law Science Information (Institution of Law Science, Ministry of Justice). 2017;(3):53-63.

21. Nhu Q. Luật Cạnh tranh chỉ là đồ... trang trí [The competition law is... the ornament]. Phap luat TPHCM online [Internet][cited 2020 Jan 23]. 2017;p. 5-36. Available from: https://plo.vn/kinh-te/luat-canh-tranh-chi-la-dotrang-tri-701495.html. 
22. Carl K, Donald FT. Antitrust Policy: An Economic and Legal Analysis (be written in 1959). In: The Political Economy of the Sherman Act: The First One Hundred Years, Editor Sullivan E Thomas. 1 edition. New York: Oxford University Press. 1991;

23. Herbert JH. The Sherman Act and the Classical Theory of Competition (be written in 1989). In: The Political Economy of the Sherman Act: The First One Hundred Years, Editor Sullivan E Thomas. 1 edition. New York: Oxford University Press. 1991;

24. George JS. The Origin of the Sherman Act (be written in 1985). In: The Political Economy of the Sherman Act: The First One Hundred Years, Editor Sullivan E Thomas. 1 edition. New York: Oxford University Press. 1991;.

25. Orbach BY. The Antitrust Consumer Welfare Paradox. Journal of Competition Law and Economics. 2011;7(1):133-164.

26. Robert HB. The antitrust paradox: A policy at war with itself. 1st ed. New York: Basic Books. 1978;p. 484.

27. Robert HB. Legislative Intent and the Policy of the Sherman Act (be written in 1966). In: The Political Economy of the Sherman Act: The First One Hundred Years, Editor Sullivan E Thomas. 1 edition. New York: Oxford University Press. 1991;.

28. Robert HL. Wealth Transfers as the Original and Primary Concern of Antitrust: The Efficiency Interpretation Challenged (be written in 1982). In: The Political Economy of the Sherman Act: The First One Hundred Years, Editor Sullivan E Thomas. 1 edition. New York: Oxford University Press. 1991;

29. Rudolph JP. The Rule of Reason in Antitrust Law: Property Logic in Restraint of Competition (be written in 1989). In: The Political Economy of the Sherman Act: The First One Hundred Years, Editor Sullivan E Thomas. 1 edition. New York: Oxford University Press. 1991.

30. Richard H. What Happened to the Antitrust Movement? (be written in 1970). In: The Political Economy of the Sherman Act: The First One Hundred Years, Editor Sullivan E Thomas. 1st ed. New York, US: Oxford University Press. 1991;

31. First H. Antitrust in Japan: The Original Intent. Pacific Rim Law \& Policy Journal. 2000;9(1):72.

32. FTC. The Antitrust Laws [Internet]. [cited 2019 Jun 25]. 2013;Available from: https://www.ftc.gov/tips-advice/ competition-guidance/guide-antitrust-laws/antitrust-laws.

33. DOJ. The Antitrust Division's Mission [Internet]. [cited 2020 Jan 29]. 2015;Available from: https://www.justice.gov/atr/mission.

34. DOJ, FTC. The 2010 Horizontal Merger Guidelines. 2010;.

35. Abir D. Monopoly and Merger Regulation in South Korea and Japan: A Comparative Analysis. Berkeley Journal of International Law. 1996;13(2):143.

36. Brill CA, Carlson BA. US and Japanese Anti-monopoly Policy and the Extraterritorial Enforcement of Competition Laws. The International Lawyer. 1999;33(1):75-118.

37. First $\mathrm{H}$. Antitrust enforcement in Japan. Antitrust Law Journal. 1995;64(1):137-182.

38. Wakui M. Antimonopoly Law: Competition Law and Policy in Japan. 2sd ed. Independently Published. 2018;p. 330.

39. Iyori H. A Comparison of US-Japan Antitrust Law: Looking at the International Harmonization of Competition Law. Pacific Rim Law \& Policy Journal. 1995;4(1):59-91.

40. The Japanese Anti-monopoly Act. 1947;

41. Lin P. Competition policy in East Asia: the cases of Japan, the People's Republic of China, and Hong Kong. Hong Kong; 2003 Dec p. 44. Report No.: CAPS Working Paper No. 133 (17/02) CAPS;

42. Nicolae I. A comparative study between EU and Japanese Competition Law [JAEM01 Master Thesis]. [Lund, Sweden]: Lund University. 2015;

43. The JFTC's Policies Concerning Procedures of Review of Business Combination. 2011;

44. Monti M. European Competition for the 21st Century. Fordham International Law Journal. 2000;24(5):1602.

45. David G. Law and Competition in Twentieth-Century Europe: Protecting Prometheus. Oxford, New York: Oxford University Press. 2003;p. 504

46. Vallindas G. New Directions in EC Competition Policy: The Case of Merger Control. European Law Journal.
2006;12(5):636-660

47. Gerbrandy A. Rethinking Competition Law within the European Economic Constitution. Journal of Common Market Studies. 2019;57(1):127-142.

48. Whish R, Bailey D. Competition Law. 8th edition. Oxford, United Kingdom: Oxford University Press. 2015;p. 1071.

49. Jones A, Sufrin B. EU Competition Law: Text, Cases, and Materials. Sixth Edition. Oxford, New York: Oxford University Press (Text, Cases, and Materials). 2016;p. 1273.

50. Dunne N. Competition Law and Economic Regulation: Making and Managing Markets. 1st ed. London: Cambridge University Press. 2015;.

51. The Treaty of Rome 1957. 1957;.

52. The Treaty on European Union 1992. 1992;p. 34.

53. The Treaty on the Functioning of the European Union 2007. 2007;.

54. Council Regulation (EEC) No 4064/89 on the Control of Concentration between Undertakings. Vol. No 4064/ 89. Official Journal of the European Union. 1989;

55. Council Regulation (EC) No 139/2004 on the Control of Concentration between Undertakings. Vol. No 139/2004. Official Journal of the European Union. 2004;

56. Levy N. EU Merger Control: From Birth to Adolescence. World Competition. 2003;26(2):195-218.

57. Christiansen A. The "more economic approach" in EU merger control. CESifo Forum. 2006;7(1):34-39.

58. Vasconcelos H. Efficiency Gains and Structural Remedies in Merger Control. The Journal of Industrial Economics. 2010;(4):742-766.

59. Carles EM, Comp D. EU merger control: How to remove anticompetitive effects? The 5th Global Merger Control Conference; Paris, France. 2017;

60. Lowe P. The Design of Competition Policy Institutions for the 21st Century: The Experience of the European Commission and DG Competition. Competition Policy Newsletter. 2008;3.

61. EU. Departments and executive agencies [Internet]. European Commission - European Commission. [cited 2020 Feb 21];Available from: https://ec.europa.eu/info/departments_en.

62. Mario M. The Future for Competition Policy in the European Union. Commission Press Release SPEECH/01/340 presented at: Merger control: Issues highlighted in the context of the GE/Honeywell Merger; London. . 2001;

63. Esteva MC. Innovation in EU merger control. The 66th ABA Section of Antitrust Law Spring Meeting; Washington. . 2018;

64. The EU's Guidelines on the assessment of non-horizontal merger. Vol. 2008/C 265/07. Official Journal of the European Union. 2008;

65. Sauter W. Squaring EU Competition Law and Industrial Policy: The Case of Broadband. Report No.: DP 2013-021. 2013;.

66. The EU's Guidelines on the assessment of horizontal merger. Vol. 2004/C 31/03. Official Journal of the European Union. . 2004;.

67. Johannes L. Competition and Consumers. The Speech of Director-General for Competition, European Commission presented at: EEA 25 years conference; Brussels. 2019.

68. Richard AP. The Chicago School of Antitrust Analysis (be written in 1979). In: The Political Economy of the Sherman Act: The First One Hundred Years, Editor Sullivan E Thomas. 1 edition. New York: Oxford University Press. . 1991;.

69. VN MOIT. Bản thuyết minh chi tiết dự thảo Luật cạnh tranh sửa đổi [Detailed Notes Of The draft of the Revised Competition Law]. VN MOIT. 2017;

70. VN MOIT. Đánh giá tác động dự án Luật cạnh tranh sửa đổi [Assessment of the revised Competition Law project's impacts]. (The included profile of the Vietnamese competition law amendment) . Hanoi. 2017;

71. Dao NB. Lựa chọn chính sách cạnh tranh trong bối cảnh hội nhập kinh tế hiện nay [Selecting competition policy under the prospect of economic harmony]. The Legislative Studies, Vietnam. 2016;11(315):43-50. 
72. Sher SA. Closed But Not Forgotten: Government Review of Consummated Mergers Under Section 7 of the Clayton Act. Santa Clara Law Review. 2004;45(1):41-98.

73. Sawyer LP. US Antitrust Law and Policy in Historical Perspective. Harvard Business School Working Paper. 2019;19:110137.

74. DOJ Antitrust Division. Antitrust Division Policy Guide to Merger Remedies, 2011. 2011;.

75. Hovenkamp H. Prophylactic Merger Policy. Hastings Law Journal. 2018;70(43):46-74.

76. Ryan Y, Wayne C. The Case against Antitrust Law: Ten Areas Where Antitrust Policy Can Move on from the Smokestack Era. 2019;

77. Steuer R. Incipiency. Loyola Consumer Law Review. 2019;31(2):155-174.

78. Elzinga KG, Howell VM. Geographic Market Definition in the Merger Guidelines: A Retrospective Analysis. Review of Industrial Organization. 2018;53(3):453-475.

79. Hue DD, Huyen NH. Những vấn đề lý luận cơ bản của Luật cạnh tranh [Basic regimes for competition law]. State and Law Review, Vietnam. 2004;9:58-71

80. Uc DT. Cạnh tranh và pháp luật cạnh tranh Việt nam hiện nay [Competition and Competition Law in Vietnam today]. State and Law Review, Vietnam. 2000;11(151):3-10.

81. OECD. Policy Roundtables on Competition policy Industrial policy and national champions 2009. OECD. 2009;

82. Schwindt R, McDaniels D. Competition Policy, Capacity Building, and Selective Adaptation: Lessons from the Japanese Experience. Washington University Global Studies Law Review. 2008;7(1):53.

83. Sakoh K. Industrial policy: The super myth of Japan's super success. Washington, DC: Asian Studies Center. (Asian Studies Center Backgrounder). 1983;

84. Seita AY, Tamura J. The Historical Background of Japan's Antimonopoly Law. University of Illinois Law Review. 1994;1994:73.

85. Matsushita M. International Trade and Competition Law in Japan. New York: Oxford University Press. (Modern Japanese law series). . 1993;p. 352.
86. Inoue A. Antitrust Enforcement in Japan: History, Rhetoric and Law of the Antimonopoly Act. Japan: Dai Ichi Hoki Co., Ltd. 2012;.

87. Murakami M. The Japanese Antimonopoly Act (Nihon no Dokusen kinshihō). Japan: Tōkyō: Shōji Hōmu. (Commercial Law). 2003;331.

88. Iyori H. Antimonopoly legislation in Japan. New York: Federal Legal Publications. 1969;.

89. First H, Shiraishi T. Concentrated Power: The Paradox of Antitrust in Japan. United States. Report No.: New York University Law and Economics Working Paper 11. 2005;p. 42.

90. Vinh LT. Tư duy phát triển và vấn đề thực thi Luât canhh tranh tại Việt nam [Development thinking and issues of competition law enforcement in Vietnam]. The Legislative Studies. 2010;15(176):42-47.

91. Hau DV. Tim lời giải cho bài toán về độc quyền và cạnh tranh [Finding solutions for questions of monopoly and competition]. The Legislative Studies, Vietnam. 2014;7(263):37-41.

92. The Vietnamese Competition Law 2018. Vol. 23/2018/QH14. 2018;.

93. Phat NN. Các khía canh pháp lý về tâp trung kinh tế và vai trò của cơ quan quản lý cạnh tranh [Several aspects of economic concentration and the role of competition authority] Legal Science Journal, Vietnam. 2007;4:14-20.

94. Mehra SK. Same Plant, Different Soil: Japan's New Merger Guidelines Symposium on Competition Law and Policy in Developing Countries. Northwestern Journal of International Law \& Business. 2006;26(3 Spring):515-526.

95. MAF Research, CMAC. Thị trường M\&A Việt Nam 2018-2019: Thay đổi để bứt phá [The M\&A Market in Vietnam in 20182019: Going for Breakthrough]. M\&A Vietnam 2019: An overall. Vietnam; 72-82. (Vietnam M\&A Outlook 2019);

96. Stoxplus. Vietnam M\&A Report 2013 [Báo cáo triển vọng M\&A Việt Nam 2013]. 2013;(3):38.

97. Vietnam M\&A Forum. Report on Merger in Vietnam in 2013 and prospects of 2014-2018: The Second Wave [Báo cáo hoạt đông M\&A Viêt Nam 2013 và triển vong 2014 - 2018: Làn sóng thứ hai]. 2014;p. 42. 


\section{Nghiên cứu so sánh về mục tiêu của luật cạnh tranh với trường hợp kiểm soát sáp nhập và các khuyến nghị cho Việt Nam}

\section{Trương Trọng Hiểu*}

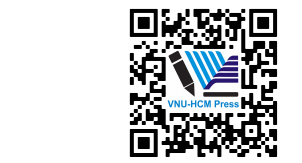

Use your smartphone to scan this QR code and download this article

\section{TÓM TẮT}

Mục tiêu của luật và chính sách cạnh tranh đóng vai trò định hướng cho quán trình thực thi lẫn xây dựng pháp luật. Dù vậy, Việt Nam đã hai lần bỏ qua việc xác định mục tiêu này khi thông qua Luật cạnh tranh năm 2004 và 2018. Kiểm soát sáp nhập trên thực tế vì vậy cũng khá lúng túng. Tiếp nối những tranh luận học thuật lâu nay, bài viết mở ra hướng tiếp cận so sánh với các nền pháp lý khác. Không phải pháp luật cạnh tranh sớm nhất châu Á là Nhật Bản hay nền pháp luật lớn và mới là Châu Âu mà luật chống độ̣c quyền Hoa Kỳ đóng vai trò đưa ra hướng tiếp cận cơ bản cho vấn đề này. Kinh nghiệm các nước cho thấy, Việt Nam có thể duy trình mô hình đa mục tiêu cùng với việc nhấn mạnh nhóm lơi ích ưu tiên cho luât canh tranh. Bỏ qua tiếp cận về cạnh tranh tự do và bình đẳng hay cạnh tranh khả thi, phân tích hướng đến cạnh tranh hiệu quả dựa trên tiếp cận chính yếu của châu Âu. Đặc biệt, quá trình thực thi chỉ thật sự hiệu quả khi các chính sách thúc đẩy cạnh tranh khác được định vị một cách rõ ràng. Tuy nhiên, chính sách công nghiệp, dù có kết nối quan trọng với chính sách cạnh tranh, không phải sẽ luôn hỗ trợ cho quá trình thực thi luật cạnh tranh. Kinh nghiệm lịch sử của Nhật Bản sẽ giới thiệu định hướng phù hợp trong xử lý mối quan hệ phức tạp giữa hai chính sách vừa có sự xung đột vừa có tính tương hỗ này. Đây là những gợi ý góp phần cho việc pháp điển hóa pháp luật cạnh tranh ở Việt Nam.

Từ khóa: Luật cạnh tranh, chính sách cạnh tranh, chính sách công nghiệp, mục tiêu, kiểm soát sáp nhập
Trường Đai hoc Kinh tế -

Luạt t,ĐHQG-HCM, Việt Nam

Liên hệ

Trương Trọng Hiểu, Trường Đại học Kinh tế -Luật,ĐHQG-HCM, Việt Nam

Email: hieutt@uel.edu.vn

Lịch sử

History

- Nhận bài: 11/8/2020

- Chấp nhận: 10/11/2020

- Xuất bản: 13/2/2021

DOI : 10.32508/stdjelm.v5i1.684

\section{Check for updates}

\section{Copyright}

(.) VNU-HCM Press. This is an openaccess article distributed under the terms of the Creative Commons Attribution 4.0 International license.

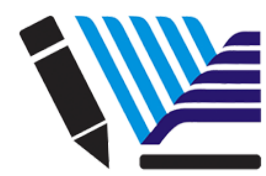

VNU-HCM Press
Cite this article : Hiểu T T. Nghiên cứu so sánh về mục tiêu của luật cạnh tranh với trường hợp kiểm soát sáp nhập và các khuyến nghị cho Việt Nam. Sci. Tech. Dev. J. - Eco. Law Manag.; 5(1):1253-1266. 